\title{
Cardiovascular disease after Escherichia coli 0157:H7 gastroenteritis
}

\author{
Patricia Hizo-Abes BHSc, William F. Clark MD, Jessica M. Sontrop PhD, Ann Young PhD, Anjie Huang MSc, \\ Heather Thiessen-Philbrook MMath, Peter C. Austin PhD, Amit X. Garg MD PhD; on behalf of the Walkerton \\ Health Study Investigators
}

Competing interests:

William Clark and Amit Garg have provided medical expert testimony on

hemolytic uremic syndrome in the United States. None declared by all other authors.

This article has been peer reviewed.

Correspondence to: Amit Garg,

amit.garg@lhsc.on.ca

CMAJ 2013. DOI:10.1503 /cmaj.112161

\section{Abstract}

Background: Escherichia coli 0157:H7 is one cause of acute bacterial gastroenteritis, which can be devastating in outbreak situations. We studied the risk of cardiovascular disease following such an outbreak in Walkerton, Ontario, in May 2000.

Methods: In this community-based cohort study, we linked data from the Walkerton Health Study (2002-2008) to Ontario's large healthcare databases. We included 4 groups of adults: 3 groups of Walkerton participants (153 with severe gastroenteritis, 414 with mild gastroenteritis, 331 with no gastroenteritis) and a group of 11263 residents from the surrounding communities that were unaffected by the outbreak. The primary outcome was a composite of death or first major cardiovascular event (admission to hospital for acute myocardial infarction, stroke or congestive heart failure, or evidence of associated procedures). The secondary outcome was first major

E scherichia coli $\mathrm{O} 157: \mathrm{H} 7$ is one cause of acute bacterial gastroenteritis, causing 63000 infections each year and 12 major outbreaks since 2006 in the United States alone. ${ }^{1,2}$ This strain was most recently implicated in the outbreak involving beef from XL Foods (September 2012), with 17 confirmed cases across Canada. $^{3}$ A similar enterohemorrhagic strain $E$. coli O104:H4 was responsible for an outbreak in Germany in May 2011, causing 3792 cases of gastroenteritis and 43 deaths. ${ }^{4,5}$

Most patients fully recover from acute gastroenteritis caused by E. coli. However, such an illness may predispose patients to long-term disease. Shiga toxin is produced by E. coli O157:H7; this toxin damages the microvasculature of the kidneys leading to hypertension ${ }^{6-13}$ and directly damages the systemic vasculature. ${ }^{14-16}$ Infected people may progress from a state of acute inflammation of the vasculature to subclinical chronic inflammation, which could promote atherosclerosis. ${ }^{17-20}$ cardiovascular event censored for death. Adults were followed for an average of 7.4 years.

Results: During the study period, 1174 adults $(9.7 \%)$ died or experienced a major cardiovascular event. Compared with residents of the surrounding communities, the risk of death or cardiovascular event was not elevated among Walkerton participants with severe or mild gastroenteritis (hazard ratio [HR] for severe gastroenteritis $0.74,95 \%$ confidence interval [CI] 0.38-1.43, mild gastroenteritis HR 0.64, $95 \% \mathrm{Cl}$ 0.42-0.98). Compared with Walkerton participants who had no gastroenteritis, risk of death or cardiovascular event was not elevated among participants with severe or mild gastroenteritis.

Interpretation: There was no increase in the risk of cardiovascular disease in the decade following acute infection during a major $E$. coli 0157:H7 outbreak.
In Walkerton, Ontario, in May 2000, heavy rains transported bovine fecal matter into the town's well, contaminating the inadequately chlorinated municipal water supply with $E$. coli O157:H7. ${ }^{21}$ Over 2300 people developed acute gastroenteritis, and 7 people died..$^{22}$ The unique circumstances of this outbreak provided a rare opportunity to study the natural history following exposure to this pathogen in a single cohort. ${ }^{23}$ Other outbreaks have been geographically dispersed, making it difficult to track cases..$^{24,25}$

In Walkerton, affected individuals were followed annually in a clinic to assess their longterm outcomes (Walkerton Health Study, 20022008). We previously reported that adults who experienced acute gastroenteritis during the outbreak had a higher than expected incidence of hypertension, chronic kidney disease and selfreported cardiovascular disease in follow-up. ${ }^{23}$ However, $46 \%$ of participants were lost to followup by the end of the study, and there were limitations associated with the assessment of cardio- 
vascular disease by participant recall. Thus, we conducted an expanded and extended follow-up study, linking the Walkerton study data to Ontario's health care databases. Our objective was to more accurately determine the 10 -year risk of major cardiovascular events after exposure to E. coli $\mathrm{O} 157: \mathrm{H} 7$.

\section{Methods}

\section{Design, setting and population}

In this community-based cohort study, we linked data from the Walkerton Health Study to Ontario's health care databases. We previously found that the Walkerton study cohort and the Walkerton population were demographically similar, aside from a slight overrepresentation of women and a slight underrepresentation of elderly people in the Walkerton study cohort. ${ }^{26}$ Population sampling and other methodologic details for the Walkerton Health Study are provided elsewhere..$^{23,27}$

The date of enrollment in the Walkerton study was the first day of follow-up, referred to as the index date (Jan. 3, 2002, to Dec. 11, 2002). In the current study, we included 4 groups of adults aged 40-89 years on the index date: 3 groups were from the Walkerton study (adults with no, mild or severe gastroenteritis during the outbreak) and 1 control group comprised of residents from the surrounding communities that were unaffected by the outbreak. Validated criteria were used to assess illness severity (presence and duration of diarrheal illness, bloody diarrhea, abdominal pain, fever or positive stool culture for E. coli O157:H7). ${ }^{28}$ Self-reported illness was confirmed by medical-record audit when possible. ${ }^{28}$

For the control group, we considered residents of geographically proximal towns that were demographically similar to Walkerton (population 4851 in 2001; ${ }^{29}$ Appendix 1, available at www.cmaj.ca/lookup/suppl/doi:10.1503 /cmaj.112161/-/DC1). This comparison group was created entirely from provincial health care databases, which contained relevant baseline data for the entire population of these communities (all Ontario residents have universal access to hospital and physician services).

Residents of the surrounding communities were randomly assigned an index date according to the distribution of such dates among the Walkerton participants. We applied the same eligibility criteria (Appendix 2, available at www.cmaj.ca /lookup/suppl/doi:10.1503/cmaj.112161/-/DC1) to all groups (Figure 1).

We excluded people with a history of chronic gastrointestinal disease before the outbreak (Jan. 1, 1991 to May 17, 2000) because assessment of acute gastroenteritis during the outbreak would be unreliable. We also excluded people with evidence of a previous cardiovascular event, hemolytic uremic syndrome or who lived in a long-term care facility before the index date.

All participants were followed from their index date until Mar. 31, 2010 (10 yr after the outbreak), death or emigration from the province.

\section{Data sources}

We used multiple databases to determine the cohorts, baseline characteristics and outcomes. The dataset from the Walkerton Health Study contains information on acute illness during the outbreak. ${ }^{28}$ The Canadian Institute for Health Information's Discharge Abstract Database contains diagnostic and procedural information for all hospital admissions in Ontario. The Ontario Health Insurance Plan database contains all claims for inpatient and outpatient physician services, and the Ontario Registered Persons Database contains demographic and vital status information for all Ontario residents..$^{30}$ The databases and the linked dataset were held securely in a deidentified form and were analyzed at the Institute for Clinical Evaluative Sciences. These databases have been used extensively in populationbased health outcomes research and are essentially complete for the study variables. ${ }^{31-35}$

\section{Outcomes}

The primary outcome was a composite of death or first major cardiovascular event (admission to hospital for acute myocardial infarction, stroke or congestive heart failure, or procedures such as coronary artery bypass graft surgery, coronary angioplasty, carotid endarterectomy, abdominal aortic aneurysm repair, aortic bypass or peripheral vascular bypass surgery) as defined using validated codes in Appendix 3 (available at www.cmaj.ca /lookup/suppl/doi:10.1503/cmaj.112161///DC1). ${ }^{36-44}$ The secondary outcome was first major cardiovascular event censored for death.

\section{Statistical analysis}

We compared baseline characteristics (Appendix 4, available at www.cmaj.ca/lookup/suppl/doi:10 $.1503 / \mathrm{cmaj} .112161 /$-/DC1) across the 4 groups using analysis of variance, Kruskal-Wallis or $\chi^{2}$ tests as appropriate. We included age (per yr) and sex in all multivariable models. We retained the following variables if their inclusion changed the associate between acute gastroenteritis and cardiovascular disease by more than 5\%:45-49 socioeconomic status (assessed by use of neighbourhood income quintile, a household sizeadjusted measure of income), ${ }^{50}$ a measure of comorbidity (Johns Hopkins Aggregated Diagnosis Groups), ${ }^{51}$ diabetes, chronic obstructive 
pulmonary disease or hypercholesterolemia at the index date, number of physician visits in the 2 years before the outbreak, and presence of hypertension or chronic kidney disease before the outbreak. We used a Cox proportional hazard regression model to calculate hazard ratios (HRs) and 95\% confidence intervals (CIs). For the primary analysis, adults from surrounding communities served as the reference group. We confirmed the proportionality assumption using a time-dependent interaction..$^{52}$

\section{Results}

\section{Baseline characteristics}

Our cohort included 898 people from the Walkerton Health Study (153 with severe gastroenteritis, 414 with mild gastroenteritis and 331 with no gastroenteritis during the outbreak) and 11263 residents of surrounding communities (Figure 1). Compared with the Walkerton participants, residents of the surrounding communities were slightly older, more likely to be male and have fewer comorbidities, and they were less likely to be in the middle socioeconomic class. Those who experienced severe gastroenteritis during the outbreak were more likely than residents of surrounding communities to have had chronic kidney disease and to have had more visits to their family physician before the outbreak (Table 1). Of the 12161 adults in this study, only 285 (2.3\%) were lost to follow-up over an average of 7.4 years (1.1\% of the Walkerton participants and $2.4 \%$ of the residents of surrounding communities).

\section{Outcomes}

There were 1174 deaths or major cardiovascular events during the study period: 1115 (9.9\%) among residents of surrounding communities; 28 $(8.5 \%)$ among those who had no gastroenteritis; $22(5.3 \%)$ among those who had mild gastroenteritis; and $9(5.9 \%)$ among those who had severe gastroenteritis (Table 2). Overall, there were 563 major cardiovascular events: 536 (4.8\%) among residents of surrounding communities, $8(2.4 \%)$ among those who had no gas-

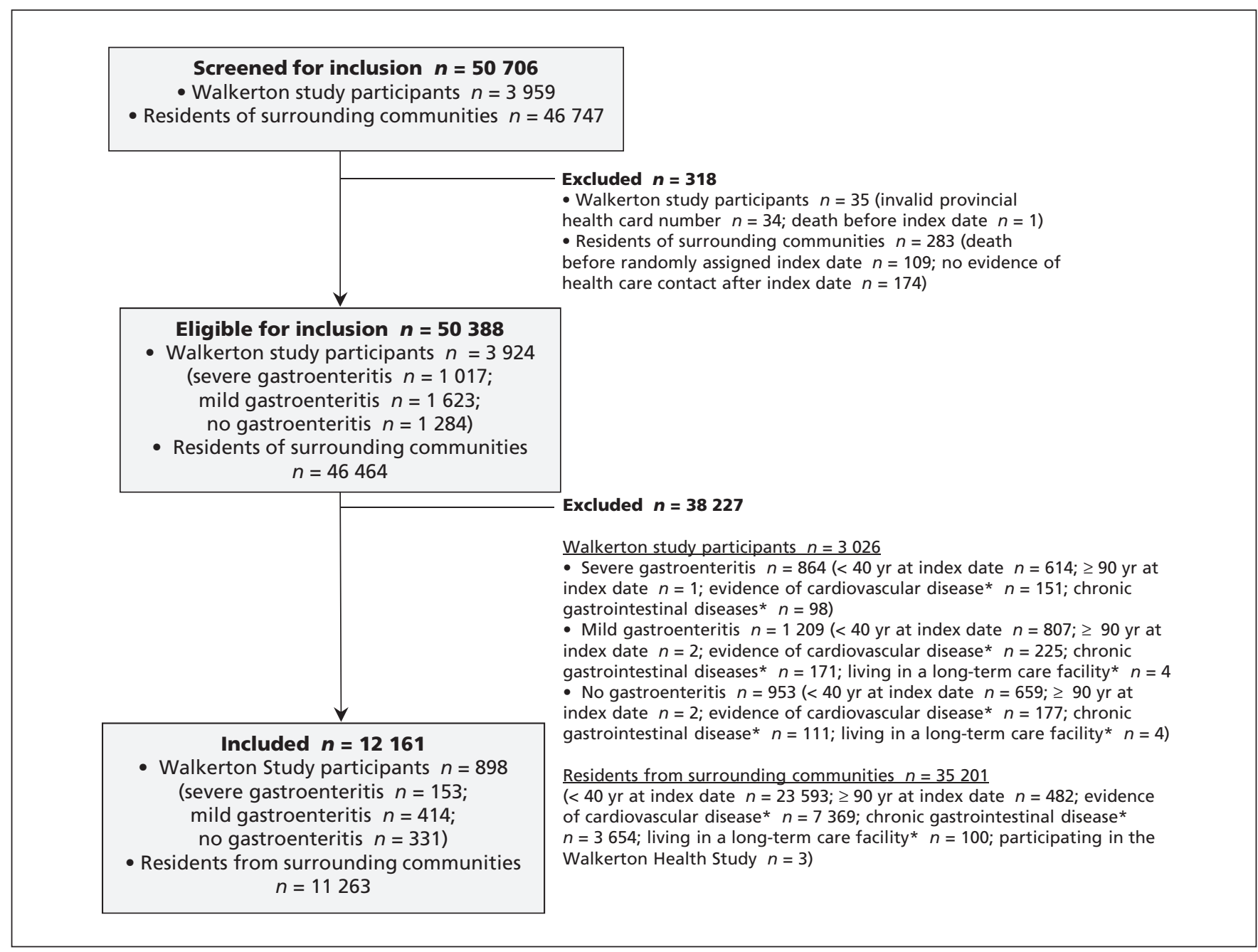

Figure 1: Selection of participants for inclusion in the study. *From Jan. 1, 1991, to May 17, 2000. 
troenteritis, $13(3.1 \%)$ among those who had mild gastroenteritis, and $6(3.9 \%)$ among those who had severe gastroenteritis. Compared with residents of surrounding communities, the adjusted hazard ratio for death or major cardiovascular event was not elevated among those with severe gastroenteritis during the outbreak (HR 0.74 [95\% CI 0.38-1.43]), and the hazard ratio was significantly decreased among those with mild gastroenteritis (HR 0.64 [95\% CI 0.42-0.98]). Similar patterns were seen for death-censored cardiovascular events (severe: HR 1.04 [95\% CI 0.46-2.33]; mild: HR 0.75 [95\% CI 0.43-1.30]) and death from all causes (severe: HR 0.39 [95\% CI 0.13-1.21], mild: HR 0.52 [95\% CI 0.29-0.97]).

\section{Additional planned analyses}

We repeated the above analyses using only Walkerton study participants. In this analysis, we considered adults who had no gastroenteritis during the outbreak to be the reference group (Table 3). Additional baseline characteristics, including objective measures of kidney function (serum creatinine, urine protein, urine albumin/creatinine ratio) at the index date were not different between the 3 groups (Appendix 5, available at www.cmaj .ca/lookup/suppl/doi:10.1503/cmaj.112161/-/DC1). The hazard for death or major cardiovascular events was not elevated among Walkerton participants with severe or mild gastroenteritis during the outbreak compared with Walkerton participants with no symptoms (severe: HR 0.75 [95\% CI 0.35-1.59]); mild: HR 0.63 [95\% CI 0.36-1.10]).

\section{Post-hoc analyses}

Health care surveillance in Walkerton intensified in response to the outbreak through extra physician clinics focused on hypertension control. Angiotensin-converting enzyme (ACE) inhibitors and angiotensin receptor blockers (ARBs) were preferentially prescribed given concerns about the

Table 1: Baseline characteristics of included participants from the Walkerton Health Study and from the surrounding communities.

\begin{tabular}{|c|c|c|c|c|c|}
\hline \multirow[b]{2}{*}{ Characteristics $\dagger$} & \multirow{2}{*}{$\begin{array}{c}\text { Residents of } \\
\text { surrounding } \\
\text { communities, } \\
\text { no. }(\%)^{*} \\
n=11263\end{array}$} & \multicolumn{3}{|c|}{$\begin{array}{l}\text { Walkerton Health Study participants, } \\
\text { no. }(\%)^{*}\end{array}$} & \multirow[b]{2}{*}{$\begin{array}{l}p \\
\text { value }\end{array}$} \\
\hline & & $\begin{array}{c}\text { No } \\
\text { gastroenteritis } \\
n=331\end{array}$ & $\begin{array}{c}\text { Mild } \\
\text { gastroenteritis } \\
n=414\end{array}$ & $\begin{array}{c}\text { Severe } \\
\text { gastroenteritis } \\
n=153\end{array}$ & \\
\hline Women & $5856(52.0)$ & $195(58.9)$ & $231(55.8)$ & $91(59.5)$ & 0.01 \\
\hline Age, yr, mean \pm SD & $54 \pm 11$ & $54 \pm 10$ & $52 \pm 9$ & $52 \pm 10$ & 0.002 \\
\hline \multicolumn{6}{|c|}{ Neighbourhood income quintile } \\
\hline 1-2 (lowest) & $4311(38.2)$ & $103(31.1)$ & $132(31.9)$ & $54(35.3)$ & $<0.001$ \\
\hline 3 (middle) & $2410(21.4)$ & $153(46.2)$ & $175(42.3)$ & $65(42.5)$ & \\
\hline 4-5 (highest) & $4542(40.3)$ & $75(22.6)$ & $107(25.9)$ & $34(22.2)$ & \\
\hline $\begin{array}{l}\text { Median number of } \\
\text { comorbidities§ (IQR) }\end{array}$ & $3(2-5)$ & $4(2-5)$ & $4(2-6)$ & $4(2-6)$ & $<0.001$ \\
\hline Hypertensionף & $1788(15.9)$ & $62(18.7)$ & $62(15.0)$ & $22(14.4)$ & 0.5 \\
\hline Chronic kidney diseaseף & $737(6.5)$ & $23(6.9)$ & $40(9.7)$ & $21(13.7)$ & $<0.001$ \\
\hline Diabetes** & $609(5.4)$ & $12(3.6)$ & $24(5.8)$ & $9(5.9)$ & 0.5 \\
\hline $\begin{array}{l}\text { Chronic obstructive } \\
\text { pulmonary disease** }\end{array}$ & $759(6.7)$ & $16(4.8)$ & $14(3.4)$ & $10(6.5)$ & 0.03 \\
\hline Hypercholesterolemia** & $2209(19.6)$ & $71(21.5)$ & $87(21.0)$ & $35(22.9)$ & 0.6 \\
\hline Psychiatric history** & $491(4.4)$ & $10(3.0)$ & $17(4.1)$ & $10(6.5)$ & 0.4 \\
\hline $\begin{array}{l}\text { Median no. of visits to a } \\
\text { family physician in the } 2 \\
\text { years before outbreak (IQR) }\end{array}$ & $4(2-9)$ & $5(2-9)$ & $5(2-9)$ & $6(3-10)$ & $<0.001$ \\
\hline \multicolumn{6}{|c|}{$\begin{array}{l}\text { Note: IQR = interquartile range, SD = standard deviation. } \\
\text { *Unless otherwise indicated. } \\
\text { †Assessed at index date (enrollment in the Walkerton Health Study or a randomly assigned date for residents of the } \\
\text { surrounding communities). } \\
\text { ‡Differences across the } 4 \text { groups were analyzed by analysis of variance, Kruskal-Wallis or } \chi^{2} \text { tests as appropriate. } \\
\text { §Based on Johns Hopkins Aggregated Diagnosis Groups (assessment period: May } 17,1998, \text { to May } 17,2000 \text { ). } \\
\text { ПAssessment of hypertension (May } 17,1997, \text { to May } 17,2000 \text { ) and chronic kidney disease (January } 1991, \text { to May } 17,2000) \text { by } \\
\text { health care database codes was restricted to the period before the outbreak because these conditions could develop as a result } \\
\text { of the outbreak and mediate the relation with cardiovascular disease. } \\
* * \text { Assessment period: January } 1991 \text { to index date. }\end{array}$} \\
\hline
\end{tabular}


long-term renal effects of E. coli $\mathrm{O} 157: \mathrm{H} 7$. To examine whether differential health care played a role in preventing outcomes, we compared the proportion of prescriptions for antihypertensive medications in the years before and after the study (Appendix 6, available at www.cmaj.ca /lookup/suppl/doi:10.1503/cmaj.112161/-/DC1). We restricted this analysis to those aged 66 to 76 because prescription drug coverage is a universal benefit to Ontarians aged 65 years and older.

The overall rates of antihypertensive prescriptions were similar between the general population and Walkerton participants in 1999 (28\% v. 30\%, respectively) and 2009 (53\% v. 52\%, respectively). Between 1999 and 2009, prescriptions for ACE inhibitors or ARBs rose from $\leq 7 \%$ to $34 \%$ among Walkerton participants and from $14 \%$ to $40 \%$ among residents of surrounding communities.

To contrast the results of the current study with those from our previous report, which described cardiovascular events assessed by participant recall, we compared self-reported cardiovascular events and events documented in the health care databases. Most (81\%) of the hospitalizations for a cardiovascular event captured in Ontario data- bases were also reported by Walkerton study participants; however, only $57 \%$ of self-reported cardiovascular events were corroborated by database codes for cardiovascular-related hospitalization (data not shown). Differential reporting by severity of gastroenteritis was not evident.

\section{Interpretation}

We found that the 10-year risk for cardiovascular disease was not higher among adults who had severe gastroenteritis and was actually lower among those who had mild gastroenteritis during an $E$. coli $\mathrm{O} 157: \mathrm{H} 7$ outbreak.

We previously found increased risks of hypertension, chronic kidney disease and self-reported cardiovascular disease among adults who experienced acute gastroenteritis after drinking water contaminated with E. coli O157:H7.23,27 Although we used objective, standardized measures to diagnose hypertension and chronic kidney disease, our previous study relied on participant recall of major cardiovascular events, and there was significant loss to follow-up. This prompted us to conduct a more accurate assessment of cardiovascular risk by linking data from the Walker-

Table 2: Death and major cardiovascular events during the study period among people who experienced mild gastroenteritis $(n=414)$, severe gastroenteritis $(n=153)$ or no gastroenteritis $(n=331)$ during the Escherichia coli O157:H7 outbreak and among a control population $(n=11263)$ from the surrounding communities

\begin{tabular}{|c|c|c|c|c|}
\hline \multirow[b]{2}{*}{ Group } & \multirow[b]{2}{*}{ No. $(\%)$} & \multirow{2}{*}{$\begin{array}{l}\text { No. of events per } \\
1000 \text { person- } \\
\text { years }\end{array}$} & \multicolumn{2}{|c|}{ Hazard ratio ( $95 \%$ confidence interval) } \\
\hline & & & Unadjusted & Adjusted* \\
\hline Residents of surrounding communities & $1115(9.9)$ & 13.4 & 1.0 (ref) & 1.0 (ref) \\
\hline \multicolumn{5}{|l|}{ Walkerton Health Study participants } \\
\hline Severe gastroenteritis & $9(5.9)$ & 7.9 & $0.60(0.31-1.12)$ & $0.74(0.38-1.43)$ \\
\hline \multicolumn{5}{|c|}{ Major cardiovascular event (death censored) } \\
\hline Residents of surrounding communities & $536(4.8)$ & 6.5 & 1.0 (ref) & 1.0 (ref) \\
\hline \multicolumn{5}{|l|}{ Walkerton Health Study participants } \\
\hline \multicolumn{5}{|l|}{ Death (all causes) } \\
\hline Residents of surrounding communities & $684(6.1)$ & 8.1 & 1.0 (ref) & 1.0 (ref) \\
\hline \multicolumn{5}{|l|}{ Walkerton Health Study participants } \\
\hline No gastroenteritis & $20(6.0)$ & 8.0 & $1.0(0.64-1.55)$ & $1.29(0.82-2.01)$ \\
\hline Mild gastroenteritis & $10(2.4)$ & 3.1 & $0.39(0.21-0.71)$ & $0.52(0.29-0.97)$ \\
\hline Severe gastroenteritis & $\dagger$ & $\dagger$ & $\dagger$ & $0.39(0.13-1.21)$ \\
\hline \multicolumn{5}{|c|}{$\begin{array}{l}\text { *Adjusted for age, sex, neighbourhood income quintile, number of comorbidities, number of family physician visits in the } 2 \text { years before the outbreak, chronic } \\
\text { obstructive pulmonary disease, diabetes, hypercholesterolemia and chronic kidney disease before the outbreak. } \\
\text { tNot reported because of count data less than } 6 \text {. With such low counts, there is a risk of reidentification using Institute for Clinical Evaluative Sciences data. This is } \\
\text { under the agreement between the Institute for Clinical Evaluative Sciences and the privacy officer of Ontario. }\end{array}$} \\
\hline
\end{tabular}


ton Health Study to Ontario's health care databases, allowing the use of administrative codes to determine outcomes, which is more reliable than self-report. Only 57\% of self-reported cardiovascular events were corroborated by validated database codes for cardiovascular-related hospitalization. No association between acute gastroenteritis and cardiovascular-related events was evident.

These discrepant results suggest 2 possible scenarios: either there is no causal link between E. coli $\mathrm{O} 157: \mathrm{H} 7$ gastroenteritis and cardiovascular events, or an association exists but we were unable to detect it in the present study. Despite the robust association with hypertension, ${ }^{23,27}$ it is possible that the biological mechanisms thought to link E. coli O157:H7 and cardiovascular disease are inadequate to precipitate major cardiovascular events - or perhaps 10 years is not long enough for such events to manifest. Alternatively, by virtue of participating in the Walkerton study, participants received extra health care and screening for hypertension and kidney disease. ${ }^{53}$ These risk factors for cardiovascular disease are asymptomatic and often go untreated in the absence of active surveillance, so diagnosis and treatment of these conditions may have been greater for Walkerton participants compared with their unexposed counterparts in the surrounding communities.
Among Walkerton participants with hypertension, the proportion receiving treatment increased from $18 \%$ to $77 \%$ during follow-up, and the overall proportion with elevated systolic/diastolic blood pressure (> 140/90 mm Hg) decreased from $25 \%$ to $20 \% .^{53}$ To examine this further, we compared the rates of antihypertensive prescription use before and after the study among those with provincial drug benefits. Overall rates of antihypertensive prescriptions were similar between groups at both time points; however, between 1999 and 2009, an 8-fold rise in prescriptions for ACE inhibitors or ARBs among Walkerton participants occurred ( $\leq 7 \%$ to $34 \%$ ), compared with a 3 -fold rise among residents of surrounding communities (14\% to $40 \%$ ). Although prescription rates were not appreciably different in 2009, it is possible that the greater relative increase in $\mathrm{ACE}$ or $\mathrm{ARB}$ use among Walkerton participants played a role in preventing cardiovascular disease among study participants.

\section{Strengths and limitations}

Our study examined long-term health outcomes after acute bacterial gastroenteritis caused by E. coli $\mathrm{O} 157: \mathrm{H} 7$ in a well-defined cohort with minimal loss to follow-up (2.3\%). All outcomes were measured using validated codes with high specifici-

Table 3: Death or major cardiovascular event after Escherichia coli 0157:H7 gastroenteritis among participants in the Walkerton Health Study with no gastroenteritis $(n=331)$, mild gastroenteritis $(n=414)$ or severe gastroenteritis $(n=153)$




ties and positive predictive values..$^{36-44}$ The method of determining acute gastrointestinal illness at the time of the outbreak was validated using both public health and medical records. ${ }^{28}$ Although we could not reliably determine the cause of death from our data sources, cardiovascular disease is a leading cause of death in Ontario, with an age-adjusted mortality of $29 \% .{ }^{54}$ To protect against potential immortal-time bias, ${ }^{55}$ we excluded cardiovascular events between the outbreak and each participant's index date (enrollment in the Walkerton study). ${ }^{55.56}$ There was no appreciable difference in the proportion excluded for this reason across comparison groups ( $1.75 \%$ of eligible participants).

As in other outbreak situations, multiple bacteria contaminated the water; Campylobacter jejuni was also detected, and coinfection occurred. It is possible that exposure misclassification could have attenuated the association, if one exists. However, because the infectious dose of $E$. coli $\mathrm{O} 157: \mathrm{H} 7$ is much lower than that of Campylobacter (10-100 cells v. 500-10 000 cells), ${ }^{1}$ it is unlikely that a participant with acute gastroenteritis was unexposed to E. coli $\mathrm{O} 157: \mathrm{H} 7$.

It is possible that the apparent protective association between mild illness and cardiovascular disease could have resulted from unmeasured or residual confounding if those who suffered only mild illness after infection with $E$. coli $\mathrm{O} 157: \mathrm{H} 7$ were selectively healthier than the average individual.

Finally, because of the observational nature of the study, we can only establish the lack of an association and not the lack of a causal relation. Nonetheless, the contamination of Walkerton's municipal water was a disastrous event in a welldefined population, and we controlled for many confounders using exclusions and statistical adjustments. Additionally, the absence of an elevated risk was consistent across all outcomes; unadjusted hazard ratios were either nonsignificant or less than one. This strongly supports our findings of no increased risk of cardiovascular events or death in this population.

\section{Conclusion}

This study provides evidence that the risk of major cardiovascular events was not higher in Walkerton in the decade following the E. coli O157:H7 outbreak. This may be partly explained by active surveillance and treatment for conditions such as hypertension, which may prevent cardiovascular events.

\section{References}

1. US Food and Drug Administration. Bad bug book - foodborne pathogenic microorganisms and natural toxins. 2 nd edition. Silver Spring (MD): The Administration; 2012. Avaliable: www.fda .gov/Food/FoodSafety/FoodborneIllness/FoodborneIllnessFood bornePathogensNaturalToxins/BadBugBook/default.htm.
2. E. coli outbreak investigations. Atlanta (GA): Centers for Disease Control and Prevention; 2011. Available: www.cdc.gov /ecoli/outbreaks.html (accessed 2011 July 5).

3. Public Health Agency of Canada. Public health notice: E. coli O157 illness related to beef. Ottawa (ON): The Agency; 2012. Available: www.phac-aspc.gc.ca/fs-sa/phn-asp/ecoli-1012-eng .php (accessed 2012 Nov. 1)

4. Outbreak of Shiga toxin-producing E. coli in Germany. Stockholm (Sweden); 2011. Available: http://ecdc.europa.eu/en/activities /sciadvice/Lists/ECDC\%20Reviews/ECDC_DispForm.aspx?List =512ff74f-77d4-4ad8-b6d6-bf0f23083f30\&ID=1120\&RootFolder $=\% 2 \mathrm{Fen} \% 2$ Factivities $\% 2$ Fsciadvice $\% 2$ FLists $\% 2$ FECDC $\% 20$ Reviews (accessed 2011 July 5).

5. The World Health Organization. EHEC outbreak: update 13. Geneva (Switzerland): The Organization; 2011. Available: www.euro.who.int/en/what-we-do/health-topics/emergencies /international-health-regulations/news/news/2011/06/ehec-outbreak -update-13 (accessed 2011 July 5).

6. Hughes AK, Stricklett PK, Kohan DE. Cytotoxic effect of Shiga toxin-1 on human proximal tubule cells. Kidney Int 1998;54 426-37.

7. Hughes AK, Ergonul Z, Stricklett PK, et al. Molecular basis for high renal cell sensitivity to the cytotoxic effects of shigatoxin-1: upregulation of globotriaosylceramide expression [published erratum in J Am Soc Nephrol 2003 May;14:(5)]. J Am Soc Nephrol 2002;13:2239-45.

8. Van Setten PA, van Hinsbergh VW, Van den Heuvel LP, et al. Verocytotoxin inhibits mitogenesis and protein synthesis in purified human glomerular mesangial cells without affecting cell viability: evidence for two distinct mechanisms. J Am Soc Nephrol 1997;8:1877-88

9. Matsushita K, van der Velde M, Astor BC; Chronic Kidney Disease Prognosis Consortium, et al. Association of estimated glomerular filtration rate and albuminuria with all-cause and cardiovascular mortality in general population cohorts: a collaborative meta-analysis. Lancet 2010;375:2073-81.

10. Ohmi K, Kiyokawa N, Takeda T, et al. Human microvascular endothelial cells are strongly sensitive to Shiga toxins. Biochem Biophys Res Commun 1998;251:137-41.

11. Obrig TG, Louise CB, Lingwood CA, et al. Endothelial heterogeneity in Shiga toxin receptors and responses. $\mathrm{J}$ Biol Chem 1993;268:15484-8.

12. Ruggenenti P, Noris M, Remuzzi G. Thrombotic microangiopathy, hemolytic uremic syndrome, and thrombotic thrombocytopenic purpura. Kidney Int 2001;60:831-46.

13. van Setten PA, van Hinsbergh VW, van der Velden TJ, et al Effects of TNF alpha on verocytotoxin cytotoxicity in purified human glomerular microvascular endothelial cells. Kidney Int 1997;51:1245-56.

14. Guessous F, Marcinkiewicz M, Polanowska-Grabowska R, et al. Shiga toxin 2 and lipopolysaccharide induce human microvascular endothelial cells to release chemokines and factors that stimulate platelet function. Infect Immun 2005;73:8306-16.

15. Louise CB, Obrig TG. Shiga toxin-associated hemolytic-uremic syndrome: combined cytotoxic effects of Shiga toxin, interleukin-1 beta, and tumor necrosis factor alpha on human vascular endothelial cells in vitro. Infect Immun 1991;59:4173-9.

16. Obrig TG, Del Vecchio PJ, Brown JE, et al. Direct cytotoxic action of Shiga toxin on human vascular endothelial cells. Infect Immun 1988;56:2373-8.

17. Espinola-Klein C, Rupprecht HJ, Blankenberg S, et al. Impact of infectious burden on extent and long-term prognosis of atherosclerosis. Circulation 2002;105:15-21.

18. Lowe GD. The relationship between infection, inflammation, and cardiovascular disease: an overview. Ann Periodontol 2001;6: $1-8$.

19. Mehta JL, Saldeen T, Rand K. Interactive role of infection, inflammation and traditional risk factors in atherosclerosis and coronary artery disease. J Am Coll Cardiol 1998;31:1217-25.

20. Ross R. Atherosclerosis - an inflammatory disease. $N$ Engl J Med 1999;340:115-26.

21. Salvadori MI, Sontrop JM, Garg AX, et al. Factors that led to the Walkerton tragedy. Kidney Int Suppl 2009;(112):S33-4.

22. The investigative report of the Walkerton outbreak of waterborne gastroenteritis. Owen Sound (ON): Bruce-Grey Owen Sound Health Unit; 2000.

23. Clark WF, Sontrop JM, Macnab JJ, et al. Long term risk for hypertension, renal impairment, and cardiovascular disease after gastroenteritis from drinking water contaminated with Escherichia coli $\mathrm{O} 157: \mathrm{H7}$ : a prospective cohort study. BMJ 2010;341:c6020.

24. Rangel JM, Sparling PH, Crowe C, et al. Epidemiology of Escherichia coli O157:H7 outbreaks, United States, 1982-2002. Emerg Infect Dis 2005;11:603-9. 
25. Su C, Brandt LJ. Escherichia coli O157:H7 infection in humans. Ann Intern Med 1995;123:698-714.

26. Garg AX, Macnab J, Clark W, et al. Long-term health sequelae following E. coli and Campylobacter contamination of municipal water. Population sampling and assessing non-participation biases. Can J Public Health 2005;96:125-30.

27. Garg AX, Moist L, Matsell D, et al. Risk of hypertension and reduced kidney function after acute gastroenteritis from bacteriacontaminated drinking water. CMAJ 2005;173:261-8.

28. Garg AX, Marshall J, Salvadori M, et al. A gradient of acute gastroenteritis was characterized, to assess risk of long-term health sequelae after drinking bacterial-contaminated water. $J$ Clin Epidemiol 2006;59:421-8.

29. 2006 Community profiles. Cat. no. [92-591-XWE]. Ottawa (ON): Statistics Canada; 2006.

30. Institute for Clinicial Evaluative Sciences. ICES data holdings. Toronto (ON): The Institute for; 2011. Available: www.ices .on.ca/webpage.cfm?site_id=1\&org_id=26\&morg_id=0\&gsec_id $=5314 \&$ item $\_$id $=5322$ (accessed 2010 July 6 ).

31. Siddiqui NF, Coca SG, Devereaux PJ, et al. Secular trends in acute dialysis after elective major surgery - 1995 to 2009 . CMAJ 2012;184:1237-45.

32. Shih AW, Weir MA, Clemens KK, et al. Oral bisphosphonate use in the elderly is not associated with acute kidney injury. Kidney Int 2012;82:903-8.

33. Zhao YY, Weir MA, Manno M, et al. New fibrate use and acute renal outcomes in elderly adults: a population-based study. Ann Intern Med 2012;156:560-9.

34. Garg AX, Meirambayeva A, Huang A, et al. Cardiovascular disease in kidney donors: matched cohort study. BMJ 2012;344:e1203.

35. Molnar AO, Coca SG, Devereaux PJ, e al. Statin use associates with a lower incidence of acute kidney injury after major elective surgery. J Am Soc Nephrol 2011;22:939-46.

36. Austin PC, Daly PA, Tu JV. A multicenter study of the coding accuracy of hospital discharge administrative data for patients admitted to cardiac care units in Ontario. Am Heart J 2002; 144 : 290-6.

37. Canadian Institute for Health Information. Discharge abstract database data quality re-abstraction study: Combined findings for 1999/2000 and 2000/2001. 2002. Ottawa (ON): The Institute; 2002.

38. Deyo RA, Cherkin DC, Ciol MA. Adapting a clinical comorbidity index for use with ICD-9-CM administrative databases. J Clin Epidemiol 1992;45:613-9.

39. Fisher ES, Whaley FS, Krushat WM, et al. The accuracy of Medicare's hospital claims data: progress has been made, but problems remain. Am J Public Health 1992;82:243-8.

40. Henderson T, Shepheard J, Sundararajan V. Quality of diagnosis and procedure coding in ICD-10 administrative data. Med Care 2006;44:1011-9.

41. Jha P, Deboer D, Sykora K, et al. Characteristics and mortality outcomes of thrombolysis trial participants and nonparticipants: a population-based comparison. J Am Coll Cardiol 1996;27: 1335-42.

42. Juurlink DN, Prevra C, Croxford R. Canadian Institute for Health Information Discharge Abstract Database: a validation study. Toronto (ON): Institute for Clinical Evaluative Sciences; 2006.

43. Quan H, Parsons GA, Ghali WA. Validity of information on comorbidity derived from ICD-9-CCM administrative data. Med Care 2002;40:675-85.

44. Richards J, Brown A, Homan C. The data quality study of the Canadian discharge abstract database. In: Achieving data quality in a statistical agency. Ottawa (ON): Statistics Canada; 2002.

45. Greenland S, Rothman K. Introduction to stratified analysis. In: Rothman K, Greenland S, editors. Modern epidemiology. 2nd ed. Philadelphia ( PA): Lippincott-Raven; 1998. p. 253-79.

46. Kennedy WJ, Bancroft TA. Model building for prediction in regression based upon repeated significance tests. Ann Math Stat 1971;42:1273-84.

47. Lee KI, Koval JJ. Determination of the best significance level in forward stepwise logistic regression. Comm Statist Simulation Comput 1997;26:559-75
48. Maldonado G, Greenland S. Simulation study of confounderselection strategies. Am J Epidemiol 1993;138:923-36.

49. Mickey RM, Greenland S. The impact of confounder selection criteria on effect estimation. Am J Epidemiol 1989;129:125-37.

50. Wilkins R. PCCF + Version 4J user's guide: automated geographic coding based on the Statistics Canada postal code conversion files. Ottawa $(\mathrm{ON})$ : Statistics Canada; 2007. Cat. No. 82F0086-XDB. Available: http://prod.library.utoronto.ca /datalib/codebooks/cstdli/pccf_health/pccf4j/msword.pccf4j.pdf (accessed 2012 June 6).

51. Austin PC, Walraven C. The mortality risk score and the ADG score: two points-based scoring systems for the Johns Hopkins Aggregated Diagnosis Groups to predict mortality in a general adult population cohort in Ontario, Canada. Med Care 2011;49: 940-7.

52. Kleinbaum DG, Klein M. Evaluating the proportional hazards assumption. Survival analysis. 2nd ed. New York (NY): Springer; 2005. p. 131-71.

53. Clark WF, Macnab JJ, Sontrop JM; WEL Investigators of the Walkerton Health Study. London (ON): The Walkerton Health Study, 2002-2008: final report; 2008.

54. Table 102-0552: Deaths and mortality rate, by selected grouped causes and sex, Canada, provinces and territories, annual. Ottawa (ON): Statistics Canada; 2007. Available: www5.statcan .gc.ca/cansim/a01?lang=eng (accessed 2011 July 11).

55. Shariff SZ, Cuerden MS, Jain AK, et al. The secret of immorta time bias in epidemiologic studies. J Am Soc Nephrol 2008;19: 841-3.

56. Lévesque LE, Hanley JA, Kezouh A, et al. Problem of immortal time bias in cohort studies: example using statins for preventing progression of diabetes. BMJ 2010;340:b5087.

Affiliations: From the Division of Nephrology, Department of Medicine (Hizo-Abes, Clark, Sontrop, Young, ThiessenPhilbrook, Garg), Western University, London, Ont.; the Department of Epidemiology \& Biostatistics (Sontrop, Thiessen-Philbrook, Garg) Western University, London, Ont.; the Institute for Clinical Evaluative Sciences (Huang, Austin, Garg), Toronto, Ont.

Contributors: All authors contributed to the study design, data collection and analysis, interpretation, and writing and revising the manuscript. All of the authors approved the final version submitted for publication.

Funding: This study was supported by the Institute for Clinical Evaluative Sciences (ICES), which is funded by an annual grant from the Ontario Ministry of Health and LongTerm Care (MOHLTC). The opinions, results and conclusions reported in this paper are those of the authors and are independent from the funding sources. No endorsement by ICES or MOHLTC is intended or should be inferred.

The Walkerton Health Study was funded by the Ontario Ministry of Health. The current project was funded by the Canadian Institutes of Health Research. Patricia Hizo-Abes was supported by a Summer Research Training Program grant, the Heart and Stroke Foundation and the MachGaensslen Foundation of Canada. Peter Austin was supported in part by a Career Investigator Award from the Heart and Stroke Foundation of Ontario. Amit Garg was supported by a Canadian Institutes of Health Research ClinicianScientist Award. The opinions, results and conclusions reported in this paper are those of the authors and are independent of the funding sources.

Members of the Walkerton Health Study Investigators: Drs. Stephen Collins, John Howard, Douglas Matsell, John Marshall, Jennifer Macnab, Louise Moist, Janet Pope, Marina Salvadori and Rita Suri. 